\title{
Analysis of natural radioactivity and artificial radionuclides in soil samples in the Najran region of Saudi Arabia
}

\author{
A. Al-Zahrany \& K. S. Al-Mogabes \\ Institute of Atomic Energy Research, \\ King Abdulaziz City for Science and Technology, Saudi Arabia
}

\begin{abstract}
Concentrations of ${ }^{238} \mathrm{U},{ }^{232} \mathrm{Th},{ }^{226} \mathrm{Ra},{ }^{40} \mathrm{~K}$, and ${ }^{137} \mathrm{Cs}$ in 43 soil samples obtained from Najran region were analyzed using high resolution hyper pure germanium spectrometers. The activity ranged from $1.08 \mathrm{~Bq} / \mathrm{Kg}$ to $7.76 \mathrm{~Bq} / \mathrm{Kg}, 8.56 \mathrm{~Bq} / \mathrm{Kg}$ to $49.09 \mathrm{~Bq} / \mathrm{Kg}$, 8.67 Bq/Kg to $41.54 \mathrm{~Bq} / \mathrm{Kg}, 202.85 \mathrm{~Bq} / \mathrm{Kg}$ to $993.07 \mathrm{~Bq} / \mathrm{Kg}$ and $0.08 \mathrm{~Bq} / \mathrm{Kg}$ to $7.65 \mathrm{~Bq} / \mathrm{Kg}$, respectively. The mean concentrations for all naturally occurring radio-nuclides averaged over the whole region were found to be less than the international level for soil in the United States, China, and Japan. Moreover, the average annual effective dose for Najran region was evaluated to be $0.33 \mathrm{mSv} /$ year, which is comparatively less than the annual average dose worldwide from all natural sources of exposure $(2.40 \mathrm{mSv} / \mathrm{year})$.

Keywords: natural radioactivity, Cs-137 fallout, NORM, radioactivity level in soil, Saudi Arabia.
\end{abstract}

\section{Introduction}

Naturally occurring radioactive material (NORM), arising from the decay of uranium-radium and thorium series and potassium-40, has been found in the earth's crust and soil, the underground water and even in living tissues and organs of living organisms. This presence has been recognized since the early 1930s. However, it received minimal attention until the last few decades, when the role of terrestrial radiation as the main contributor to the collective effective dose of the world's populations has been recognized (UNSCEAR [1-3]). Moreover, measurement of concentrations of some man-made radionuclides such as Cs-137 and others in soil is too important to evaluate the contribution of those 
man-made radionuclides to the population's effective dose as well as to evaluate the magnitude of the radioactive fallout in the region.

Measurement of the naturally occurring radiation and radioactivity in Saudi Arabia started in the early 1980s [4-9]. However, an intensive and systemic study of the environmental radiation levels and concentrations of natural and man-made radionuclides in soil, water and other segments of the environment has been started by the Institute of Atomic Energy Research (IAER) of KACST since 1992. The present work is a part of this systematic study. It is devoted to the study of the concentrations of naturally occurring radionuclides and Cs-137 in soil, and to the assessment of the gross gamma dose rates in selected locations in the Najran region of the Kingdom of Saudi Arabia.

Najran region is situated in the South-Western part of the Kingdom of Saudi Arabia and located between latitudes of $44^{\circ} \mathrm{E}$ to $52^{\circ} \mathrm{E}$ and longitudes of $17^{\circ} \mathrm{N}$ to $20^{\circ} \mathrm{N}$. Najran region consists of seven governorates with three geographical environments; a series of mountains in the west with elevation of $1800 \mathrm{~m}$ above the sea, valleys and plains (rich and good for cultivation) and the desert area in the east called the Empty Quarter desert. The surface area of Najran region is approximately 365,000 square kilometres which is the third largest region in the Kingdom of Saudi Arabia and divided into 54 administrative centres [10]. It has a population of $\sim 620,000[11]$.

\section{Materials and methods}

\subsection{Sampling and sample preparation}

In this research, fifty soil samples were collected from different locations throughout Najran region. The coordinates of sampling locations were determined by Global Positioning System (GPS) and the map of Najran region is shown in Figure 1. The samples were randomly selected from undisturbed sites situated in open areas far away from buildings and any other constructions, and the distance between the neighbouring sites was about 5-15 Km. The soil sample representing a given site was collected from three different points forming an equilateral triangle of $10 \mathrm{~m}$ length at a depth ranging from 0 to $30 \mathrm{~cm}$ below the surface and then the collected soil from the different points with equal portions was mixed together. The mixed soil samples were dried in open air for enough time and then dried an oven at $100^{\circ} \mathrm{C}$ for about 24 hours to achieve constant dry weight. After that, the dried soil samples were ground to obtain homogenous powder and sieved through a mesh size $2 \mathrm{~mm}$ diameter. Finally, a one litter volume of each soil sample was weighed, transferred to one litter Marinelli beakers $[9,17]$. After sealing the Marinelli beaker with a standard volume soil samples they were stored for one month to reach the secular equilibrium between the radium and thorium content of the soil samples and their daughters $[9,17]$.

\subsection{Counting system and calibration}

The samples were analyzed spectroscopically and gamma-ray spectra emitting from soil samples were measured using n-type high resolution hyper-pure 


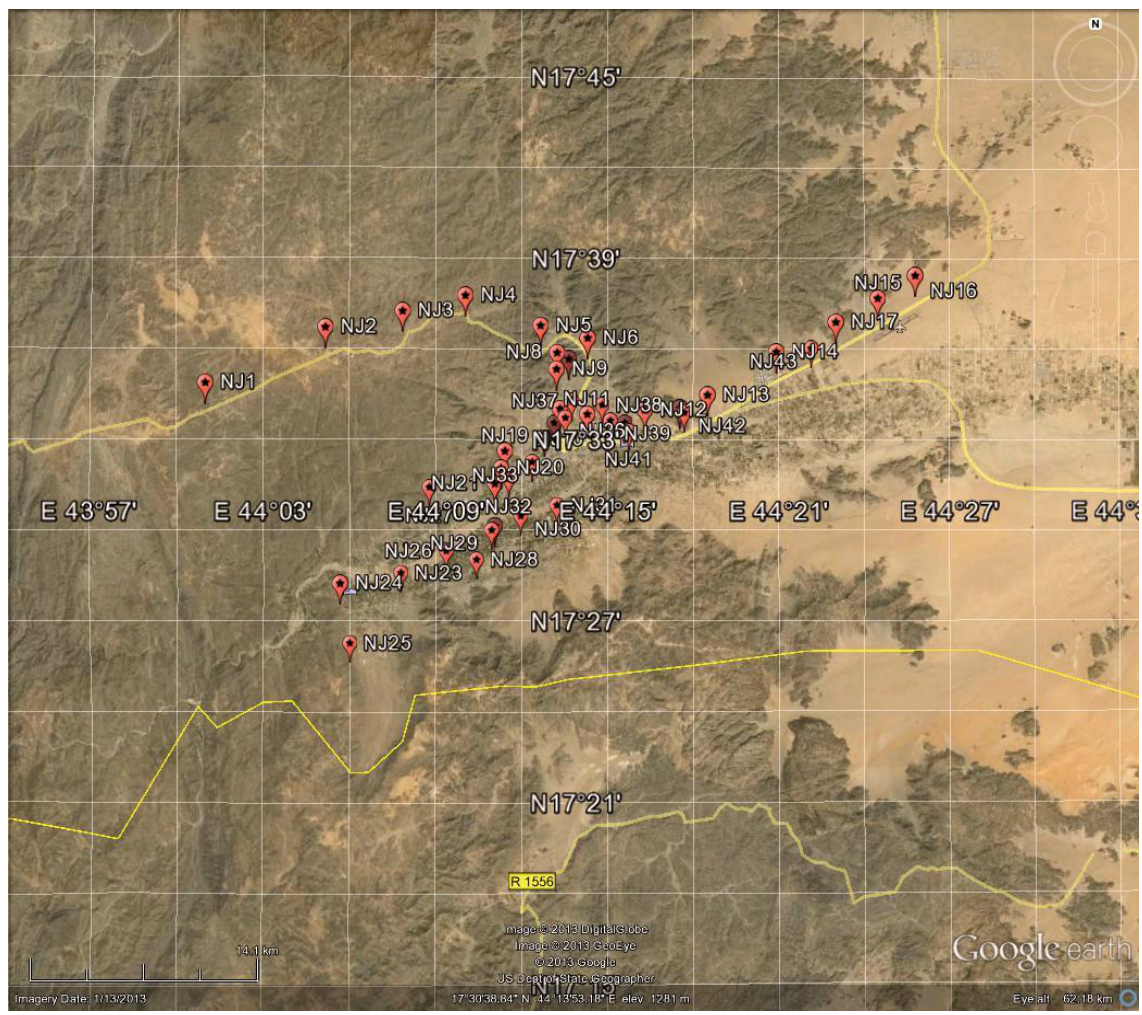

Figure 1: Map of Najran region showing the locations of the collected samples. (Map produced using Google Earth software.)

germanium spectrometers with an energy resolution better than $1.95 \mathrm{KeV}$ for the $1332 \mathrm{KeV}$ gamma-ray line of Co-60, and with relative efficiencies ranging from 20 to $40 \%$. Energy and efficiency calibration of the spectrometers in the energy range from 60 to $3000 \mathrm{KeV}$ have been carried out in the same geometrical configuration used for measuring soil samples using a set of Ba-133, Eu-152, Eu-154, Am-241 and Ra-226 standard sources. All these standard sources were distributed homogeneously in one litre Marinelli beaker.

Gamma-ray spectra emitted from the soil samples were collected in 8000 channels of the PC for a time period of 24 hours to obtain satisfactory statistical errors. The different full-energy peaks of measured spectra were identified and analyzed using Gamma Vision and Genie 2000 analysis software.

\section{Results and discussion}

Concentrations for U-238, Th-232, Ra-226, K-40, and Cs-137 of forty three sites, obtained from the analysis of the studied samples are given in table 1, in $\mathrm{Bq} / \mathrm{Kg}$ for dry soil. The uranium-238 was calculated from the $63.29 \mathrm{KeV}$ photo- 
peak which was completely isolated from any other photo-peaks in the spectra, while the Ra-226 was calculated from, 295.21, 351.92 and $609.31 \mathrm{KeV}$ photopeaks arising from its daughters in equilibrium. The 269.41, 338.40 and 911.07 $\mathrm{KeV}$ photo-peaks were used to calculate the concentration of Th-232 in equilibrium with its daughters. The 661.66 and $1460.75 \mathrm{KeV}$ gamma-ray lines were used to calculate the concentrations of Cs-137 and K-40 respectively. For Ra-226 and Th-232 the given concentrations are the average ones for the three most intensive photo-peaks. The relative errors of the measured concentrations lie between $5 \%$ for the higher experimental concentrations and increases to about $15 \%$ for lower concentrations.

The minimum and maximum concentrations for U-238, Th-232, Ra-226, K-40, and Cs-137 together with the mean values over the whole region and calculated exposure rates are given in the last three rows of the table 1 . Moreover, the distributions of the concentrations of U-238, Th-232, Ra-226, K-40, and Cs-137 among the soil samples locations are presented in Figures 2-6, respectively.

The U-238 concentrations ranged from $1.08 \mathrm{~Bq} / \mathrm{Kg}$ to $7.76 \mathrm{~Bq} / \mathrm{Kg}$ with an average value of $2.87 \mathrm{~Bq} / \mathrm{Kg}$, the $\mathrm{Th}-232$ concentrations ranged from $8.56 \mathrm{~Bq} / \mathrm{Kg}$ to $49.09 \mathrm{~Bq} / \mathrm{Kg}$ with an average value of $16.85 / \mathrm{Kg}$, the Ra-226 concentrations ranged from $8.67 \mathrm{~Bq} / \mathrm{Kg}$ to $41.54 \mathrm{~Bq} / \mathrm{Kg}$ with an average value of

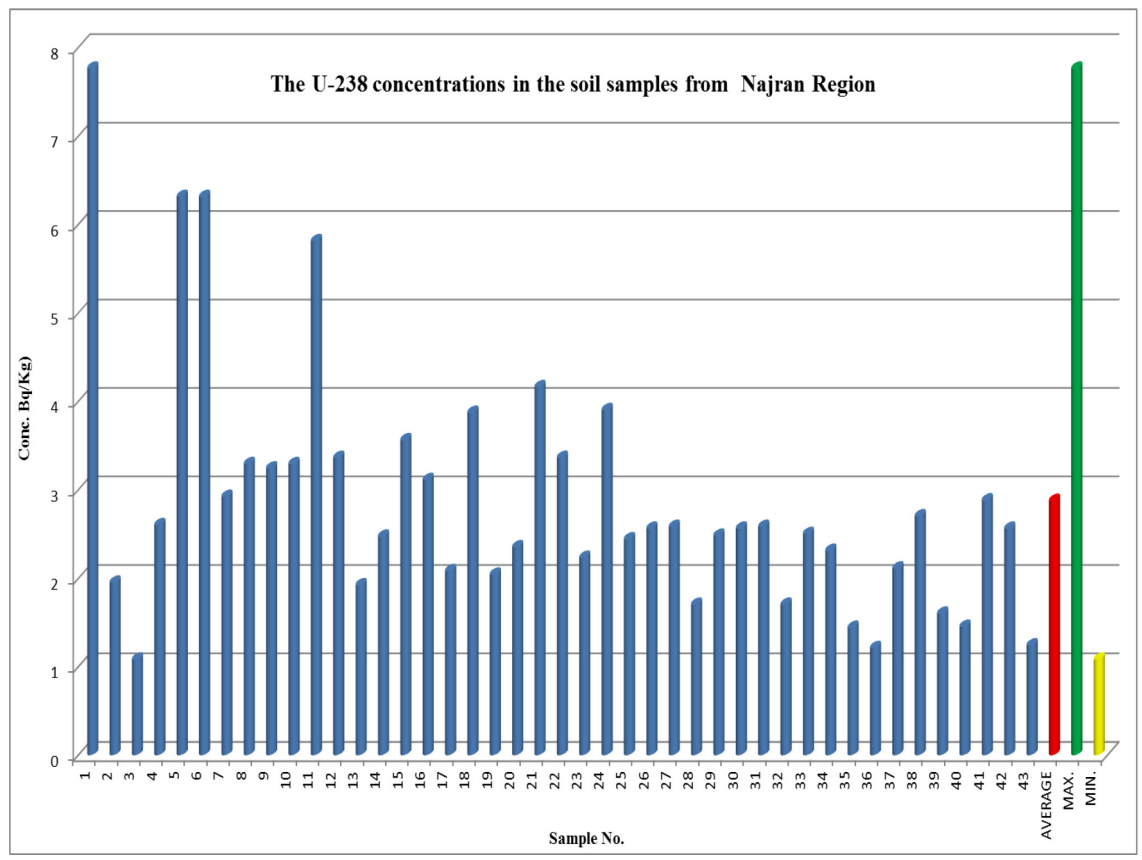

Figure 2: $\quad \mathrm{U}-238$ concentrations $(\mathrm{Bq} / \mathrm{Kg})$ in the soil samples from Najran region. 


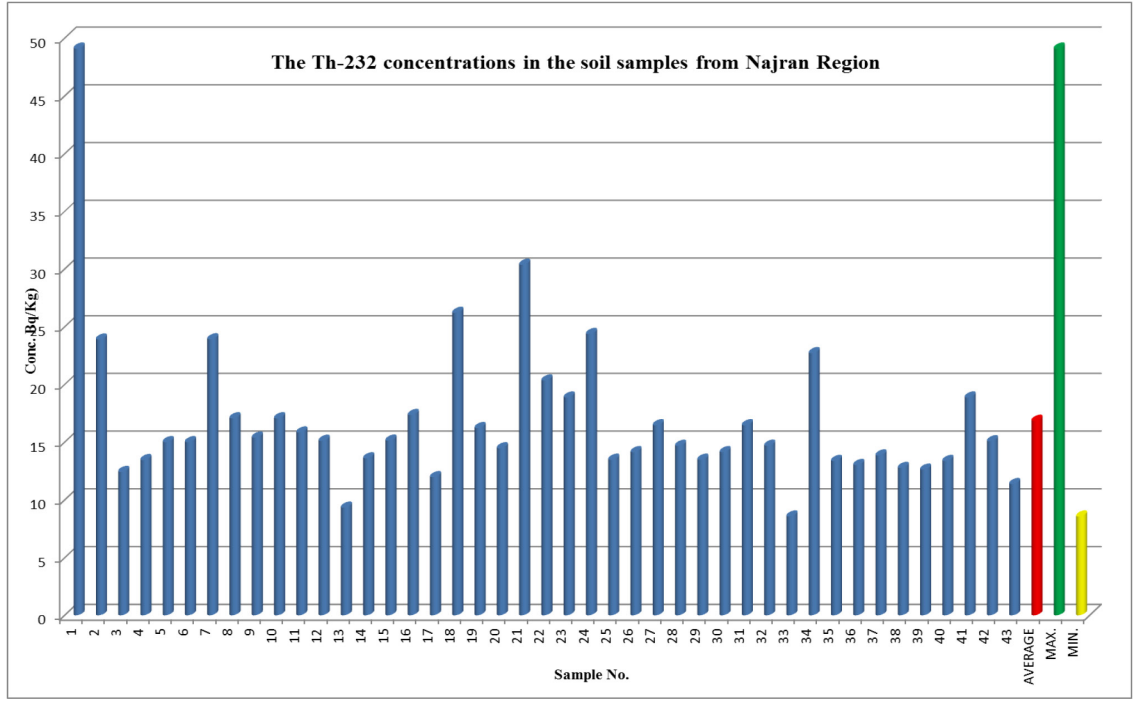

Figure 3: Th-232 concentrations $(\mathrm{Bq} / \mathrm{Kg})$ in the soil samples from Najran region.

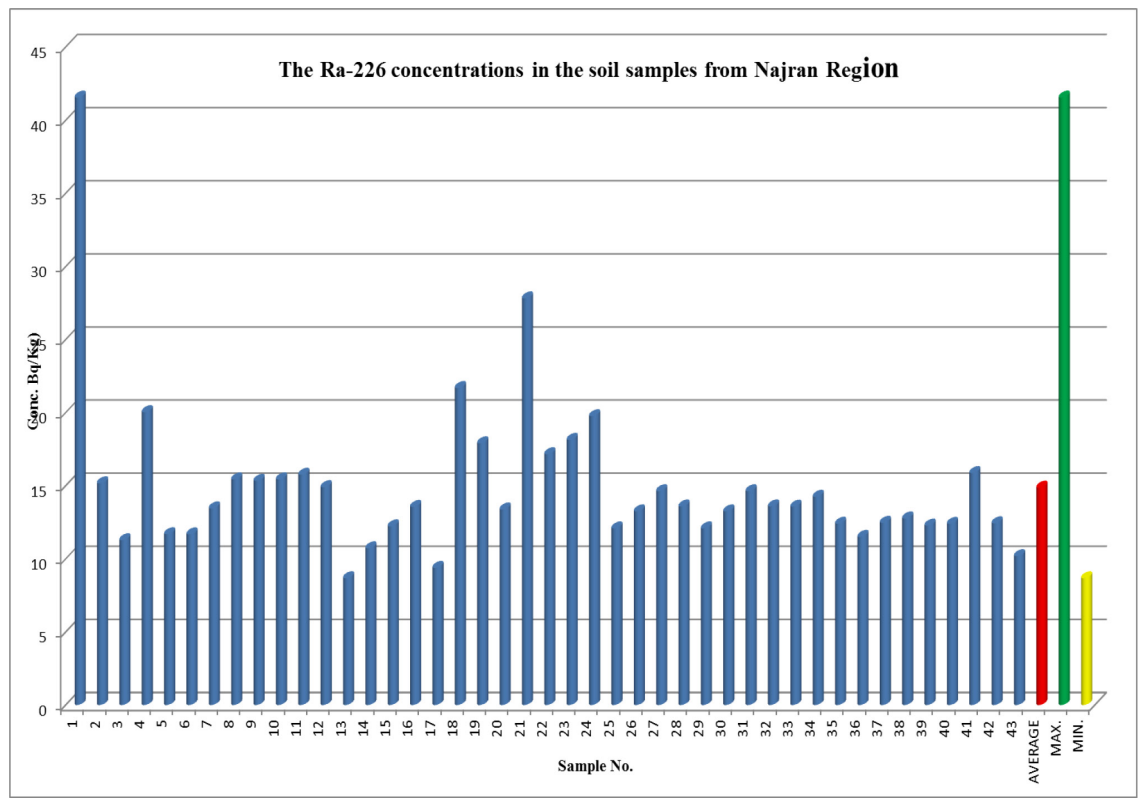

Figure 4: Ra-226 concentrations $(\mathrm{Bq} / \mathrm{Kg})$ in the soil samples from Najran region. 


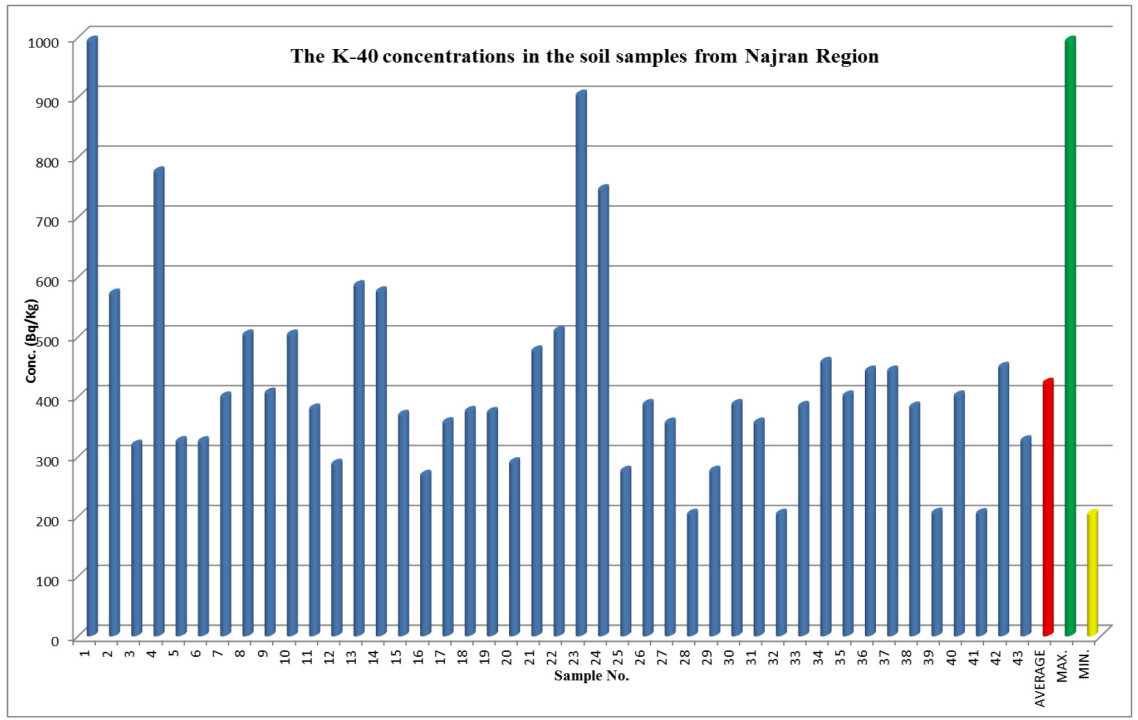

Figure 5: Ra-226 concentrations $(\mathrm{Bq} / \mathrm{Kg})$ in the soil samples from Najran region.

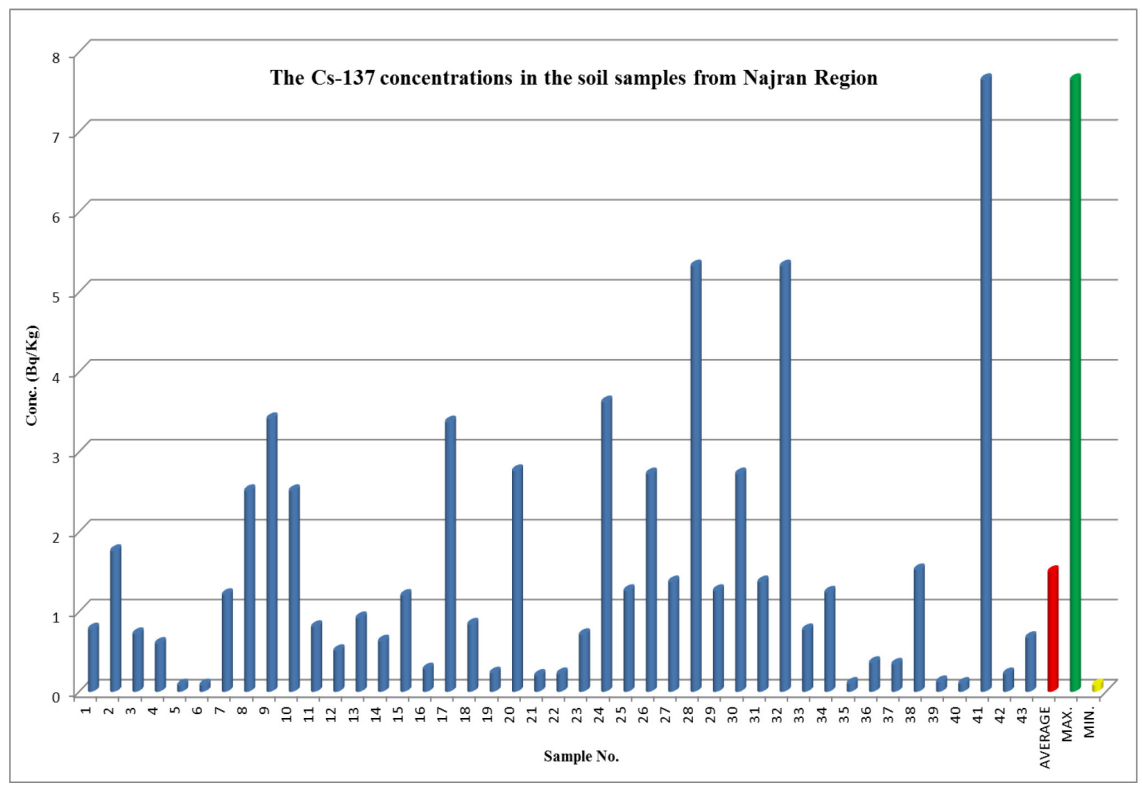

Figure 6: Ra-226 concentrations $(\mathrm{Bq} / \mathrm{Kg})$ in the soil samples from Najran region. 
Table 1: Concentrations, ranges and average concentrations of radionuclides and exposure rates in soil samples in different sites of Najran Region.

\begin{tabular}{|c|c|c|c|c|c|c|c|c|}
\hline $\begin{array}{c}\text { Sample } \\
\text { No. }\end{array}$ & $\begin{array}{l}\text { Longitude } \\
\text { North }\end{array}$ & $\begin{array}{c}\text { Latitude } \\
\text { and } \\
\text { East } \\
\end{array}$ & $\begin{array}{c}{ }^{238} \mathrm{U} \\
(\mathrm{Bq} / \mathrm{Kg})\end{array}$ & $\begin{array}{c}{ }^{232} \mathrm{Th} \\
(\mathrm{Bq} / \mathrm{Kg})\end{array}$ & $\begin{array}{c}{ }^{226} \mathrm{Ra} \\
(\mathrm{Bq} / \mathrm{Kg})\end{array}$ & $\begin{array}{c}{ }^{40} \mathrm{~K} \\
(\mathrm{~Bq} / \mathrm{Kg})\end{array}$ & $\begin{array}{c}{ }^{137} \mathrm{Cs} \\
(\mathrm{Bq} / \mathrm{Kg})\end{array}$ & $\begin{array}{c}\text { Exp. Rate } \\
\text { Calc. }(\mu R / h r)\end{array}$ \\
\hline 1 & 1734157 & 4400997 & 7.76 & 49.09 & 41.54 & 993.07 & 0.78 & 10.45 \\
\hline 2 & 1735993 & 4405168 & 1.95 & 23.89 & 15.16 & 570.58 & 1.76 & 5.16 \\
\hline 3 & 1736535 & 4407848 & 1.08 & 12.42 & 11.27 & 318.14 & 0.72 & 2.99 \\
\hline 4 & 1737051 & 4410035 & 2.60 & 13.45 & 20.03 & 774.66 & 0.60 & 5.65 \\
\hline 5 & 1736061 & 4412655 & 6.31 & 15.03 & 11.68 & 324.25 & 0.08 & 3.22 \\
\hline 6 & 1735656 & 4414301 & 6.31 & 15.10 & 11.67 & 324.00 & 0.08 & 3.22 \\
\hline 7 & 1734967 & 4413640 & 2.92 & 23.91 & 13.45 & 398.71 & 1.21 & 4.29 \\
\hline 8 & 1735174 & 4413230 & 3.29 & 17.07 & 15.43 & 502.28 & 2.51 & 4.40 \\
\hline 9 & 1734630 & 4413212 & 3.24 & 15.39 & 15.33 & 405.23 & 3.41 & 3.84 \\
\hline 10 & 1733318 & 4413331 & 3.29 & 17.07 & 15.43 & 502.28 & 2.51 & 4.40 \\
\hline 11 & 1733136 & 4414287 & 5.81 & 15.84 & 15.75 & 378.58 & 0.81 & 3.78 \\
\hline 12 & 1733275 & 4416300 & 3.36 & 15.12 & 14.90 & 286.41 & 0.51 & 3.27 \\
\hline 13 & 1733771 & 4418502 & 1.92 & 9.33 & 8.67 & 584.63 & 0.92 & 3.80 \\
\hline 14 & 1735200 & 4420917 & 2.47 & 13.60 & 10.72 & 574.26 & 0.63 & 4.18 \\
\hline 15 & 1736980 & 4424481 & 3.56 & 15.13 & 12.22 & 368.06 & 1.20 & 3.46 \\
\hline 16 & 1737742 & 4425805 & 3.11 & 17.35 & 13.55 & 267.89 & 0.28 & 3.25 \\
\hline 17 & 1736192 & 4423010 & 2.08 & 11.97 & 9.38 & 355.79 & 3.37 & 3.01 \\
\hline 18 & 1733341 & 4417533 & 3.87 & 26.20 & 21.68 & 374.51 & 0.84 & 4.86 \\
\hline 19 & 1731910 & 4411408 & 2.04 & 16.22 & 17.9 & 372.71 & 0.23 & 3.92 \\
\hline 20 & 1731342 & 4411274 & 2.35 & 14.47 & 13.37 & 288.73 & 2.76 & 3.13 \\
\hline 21 & 1730834 & 4411059 & 4.16 & 30.37 & 27.81 & 475.58 & 0.20 & 5.98 \\
\hline 22 & 1729427 & 4411049 & 3.36 & 20.34 & 17.15 & 508.37 & 0.22 & 4.76 \\
\hline 23 & 1727936 & 4407765 & 2.23 & 18.87 & 18.13 & 902.85 & 0.71 & 6.47 \\
\hline 24 & 1727527 & 4405646 & 3.90 & 24.37 & 19.75 & 744.93 & 3.62 & 6.26 \\
\hline 25 & 1725617 & 4405995 & 2.44 & 13.48 & 12.08 & 274.75 & 1.26 & 2.92 \\
\hline 26 & 1728670 & 4409354 & 2.56 & 14.13 & 13.24 & 386.09 & 2.72 & 3.54 \\
\hline 27 & 1730781 & 4408760 & 2.58 & 16.46 & 14.62 & 355.15 & 1.37 & 3.65 \\
\hline 28 & 1728384 & 4410417 & 1.70 & 14.68 & 13.58 & 202.85 & 5.32 & 2.78 \\
\hline 29 & 1729361 & 4410942 & 2.48 & 13.48 & 12.08 & 274.75 & 1.26 & 2.92 \\
\hline 30 & 1729831 & 4411960 & 2.56 & 14.13 & 13.24 & 386.09 & 2.72 & 3.54 \\
\hline 31 & 1730188 & 4413223 & 2.58 & 16.46 & 14.62 & 355.15 & 1.37 & 3.65 \\
\hline 32 & 1731070 & 4411544 & 1.70 & 14.69 & 13.58 & 202.85 & 5.32 & 2.78 \\
\hline 33 & 1731618 & 4412356 & 2.50 & 8.56 & 13.56 & 383.00 & 0.77 & 3.16 \\
\hline 34 & 1732438 & 4412785 & 2.31 & 22.71 & 14.24 & 456.55 & 1.24 & 4.51 \\
\hline 35 & 1732915 & 4413128 & 1.44 & 13.37 & 12.40 & 400.47 & 0.10 & 3.49 \\
\hline 36 & 1733087 & 4413520 & 1.21 & 13.02 & 11.50 & 442.02 & 0.36 & 3.60 \\
\hline 37 & 1733647 & 4413749 & 2.11 & 13.85 & 12.46 & 441.94 & 0.34 & 3.72 \\
\hline 38 & 1733511 & 4414808 & 2.70 & 12.77 & 12.76 & 381.81 & 1.52 & 3.39 \\
\hline 39 & 1732995 & 4415096 & 1.60 & 12.62 & 12.27 & 204.55 & 0.12 & 2.56 \\
\hline 40 & 1732922 & 4415602 & 1.45 & 13.37 & 12.39 & 400.47 & 0.10 & 3.49 \\
\hline 41 & 1732633 & 4415750 & 2.88 & 18.87 & 15.86 & 203.87 & 7.65 & 3.22 \\
\hline 42 & 1733255 & 4417692 & 2.56 & 15.08 & 12.43 & 448.19 & 0.22 & 3.83 \\
\hline 43 & 1735388 & 4422141 & 1.24 & 11.37 & 10.18 & 325.54 & 0.672 & 2.88 \\
\hline \multicolumn{3}{|c|}{ Average } & 2.87 & 16.85 & 14.86 & 421.46 & 1.50 & 3.99 \\
\hline \multicolumn{3}{|c|}{ Maximum } & 7.76 & 49.09 & 41.54 & 993.07 & 7.65 & 10.45 \\
\hline \multicolumn{3}{|c|}{ Minimum } & 1.08 & 8.56 & 8.67 & 202.85 & 0.08 & 2.56 \\
\hline
\end{tabular}

14.86 Bq/Kg, the $\mathrm{K}-40$ concentrations ranged from $202.85 \mathrm{~Bq} / \mathrm{Kg}$ to 993.07 Bq/Kg with an average value of $421.46 \mathrm{~Bq} / \mathrm{Kg}$ and the Cs-137 concentrations ranged from $0.08 \mathrm{~Bq} / \mathrm{Kg}$ to $7.65 \mathrm{~Bq} / \mathrm{Kg}$ with an average value of $1.50 \mathrm{~Bq} / \mathrm{Kg}$. For the radio-nuclides U-238, Th-232, Ra-226, and K-40 the highest concentration were found in soil sample number 1 , this may due to the geological formation of the location. 
Table 2 shows a comparison of the mean concentration of U-238, Th-232, Ra-226, K-40 and Cs-137 in the studied soil samples with the national and the international studies. It is seen from this table that the mean concentrations for all naturally occurring radionuclides averaged over in the whole region are comparatively approximately similar to the national level $[8,12,13]$. Moreover, the mean concentrations for all naturally occurring radionuclides averaged over in the whole region were found less than the international level for soil in the United States, China, and Japan [2].

Table 2: Comparison of average concentrations of radio-nuclides in soil samples of Najran region to the national and international studies $[2,8,12,13,16]$.

\begin{tabular}{|c|c|c|c|c|c|}
\hline Region & $\begin{array}{c}{ }^{\mathbf{2 3 8}} \mathbf{U} \\
(\mathrm{Bq} / \mathrm{Kg})\end{array}$ & ${ }^{\mathbf{2 3 2}} \mathbf{T h}$ & ${ }^{{ }^{\mathbf{2 2}} \mathbf{R a}}$ & ${ }^{\mathbf{4 0}} \mathbf{K}$ & ${ }^{\mathbf{1 3 7}} \mathbf{C s}$ \\
\hline This Work & 2.78 & 16.86 & 14.86 & 421.46 & 1.50 \\
\hline Al-Baha Region & 9.89 & 9.04 & 9.10 & 298.49 & 2.88 \\
\hline Riyadh Region & 12.91 & 17.79 & 17.91 & 200.9 & 2.18 \\
\hline Eastern Region & 8.82 & 3.08 & 9.79 & 136.44 & 0.66 \\
\hline Tabouk Region & 15.49 & 21.49 & 15.08 & 232.9 & 1.10 \\
\hline United States & 35 & 35 & 40 & 370 & - \\
\hline China & 33 & 41 & 32 & 440 & - \\
\hline Japan & 29 & 28 & 33 & 310 & - \\
\hline
\end{tabular}

The gamma ray effective dose for each location, calculated from measured concentrations of Th-232, Ra-226 and K-40 and the conversion factors, that are used to convert concentrations to dose rate, given in reference [15] and corrected to give the effective dose rate. Using the mean values of the calculated dose rates (3.99 $\mu \mathrm{R} / \mathrm{hr}$ ) the average annual effective dose for Najran region was evaluated to be $0.33 \mathrm{mSv} /$ year, which is comparatively less than the annual average dose (worldwide) from all natural sources of exposure, which is equal to $2.4 \mathrm{mSv} /$ year $[2,3]$.

\section{Conclusions}

The level of natural radioactivity (U-238, Th-232, Ra-226, and K-40) and manmade radionuclide such as Cs-137 in soil samples from Najran region has been measured using gamma-rays spectroscopy. The mean concentrations for all naturally occurring radio-nuclides averaged over in the whole region were found less than the international level for soil in the United States, China, and Japan. Moreover, the average annual effective dose for Najran region was evaluated to be $0.33 \mathrm{mSv} / \mathrm{year}$, which is comparatively less than the annual average dose worldwide from all natural sources of exposure $(2.40 \mathrm{mSv} / \mathrm{year})$. 


\section{References}

[1] United Nation Scientific Committee on the effect of Atomic Radiation. UNSCEAR 1993, Report to the general assembly, New York, United Nations, 1993.

[2] United Nation Scientific Committee on the Effects of Atomic Radiation (UNSEAR). Source, effects and risks of ionizing radiation, New York: United Nations, 2000.

[3] United Nation Scientific Committee on the Effects of Atomic Radiation (UNSEAR). Source, effects and risks of ionizing radiation, New York: United Nations, 2008.

[4] Martin, P., Estimate of Gamma-ray dose equivalent rates due to natural radioactivity sources in Saudi Arabia. Proc. of Int. Sym. Appl. Technol. Ionizing Radiation, Vol.3-1647, 1982.

[5] Owain, R. S., Environmental radiation monitoring., M.Sc. Thesis, College of Engineering, King Saud University, Riyadh, 1984.

[6] Al-Hussan, K. A. and Wafa, N., Environmental radiation background level in Riyadh city, Radiation Protection Dosimetry, Vol.40, No.1, 1992.

[7] Al-Haj, A. N., Measurement of natural radiation background level of Riyadh City, M.Sc. Thesis, College of Engineering, King Saud University, Riyadh, 1987.

[8] Al- Arfaj, A. M., Al-Daihan, S. K., Al-Marshad, A. I., Al-Yamani, A.Y., Al-Zhrany, A. A., Bagazi, A. O., Farouk, M. A. and Shabana, E. I., Measurements of natural and man-made radionuclides in the soil in Riyadh region. Proceedings of ASIA Congress on Radiation Protection, Beijing, 212-215 (1993).

[9] Al-Zahrany, A. A., Comparative study of radioactivity in ground water and soil in one region of the K.S.A, M.Sc. Thesis, College of Engineering, King Saud University, Riyadh, 1994.

[10] Najran University Portal, Kingdom of Saudi Arabia. http://portal.nu.edu.sa/ renains-of-najran-city/3

[11] Central Department of Statistics and Information in Kingdom of Saudi Arabia. http://www.cdsi.gov.sa/english/index.php

[12] Al-Zahrany, A. A., Al-Mogabes, K. S., and Farouk, M. A. Measurement of concentrations of the natural radio-activities and Cs-137 in the soil in the Eastern Region of Saudi Arabia. Proceedings of 3rd Arabian Conf. for Peaceful Uses of Atomic Energy, Damascus, Syria, 9-13 Dec 1996.

[13] Al-Kheliewi, A. S., Al-Mogabes, K. S., and Al-Zahrany, A. A. Measurement of natural and man-made radionuclides in soil of Tabouk region. Proceedings of 3rd Arabian Conf. for Peaceful Uses of Atomic Energy, Damascus, Syria, 9-13 Dec 1996.

[14] IAEA-TECDOC-566, the Use of Gamma-Ray Data to Define the Natural Radiation Environment, 1990.

[15] International Atomic Energy Agency, IAEA, The use of gamma-ray data to define the natural radiation environment. Vienna, Austria: Technical Report Series No.566, IAEA, 1990. 
[16] Al-Zahrany, A. A., Al-Mogabes, K.S. Measurement of concentrations of the natural radio-activities and Cs-137 in soil samples in the Al-Baha region of Saudi Arabia. 8th International Conference on Ecosystems and Sustainable Development, 13-15 April 2011 - Alicante- Spain Wessex Institute of Technology WIT Transactions on Ecology and the Environment, Vol. 144, (C) 2011 WIT Press. ISSN 1743-3541. Ecosystems and Sustainable Development VIII 435.

[17] International Atomic Energy Agency, IAEA. Measurement of radionuclides in food and the environment. Vienna, Austria: Technical Reports Series no. 295. 1989. 